\title{
The Theoretical Landscape of Service Design
}

\author{
Piia Rytilahti ${ }^{\left(\mathbb{A}^{-}\right)}$, Satu Miettinen, and Hanna-Riina Vuontisjärvi \\ Faculty of Art and Design, University of Lapland, Rovaniemi, Finland \\ \{piia.rytilahti, satu.miettinen, \\ hanna-riina.vuontisjarvi\} @ulapland.fi
}

\begin{abstract}
This conference paper discusses the theoretical landscape of service design. It will illustrate how service design is situated in a discourse on design research and outline the theoretical background of this multidisciplinary approach from a constructive and generative research perspective. In this paper, the foundation for the conceptual service design framework is based on current debates in the field. Identification of the conceptual framework is based on an analysis of co-creating service design cases that were implemented at the Service Innovation Corner (SINCO) laboratory at the Faculty of Art and Design, University of Lapland. The conceptual framework presents five themes that are closely connected with service design: (1) design research, (2) value co-creation, (3) user experience, (4) learning, and (5) citizen engagement. Using the perspective of service design, this paper attempts to elucidate the effects of service design on development and innovation processes in private and public sectors.
\end{abstract}

Keywords: Service design $\cdot$ Design research $\cdot$ Value proposition

\section{Introduction}

This conference paper is a case study based on four business cases run at the Service Innovation Corner (SINCO) laboratory of the Faculty of Art and Design at the University of Lapland [31, 32, 41]. The above-mentioned business cases are analyzed from the value proposition point of view, according to the constructive approach in which service design problem solving is accomplished through the construction of qualitative service management and managerial tools [21].

The data for the research projects were collected, documented, and analyzed using four service development cases from five organizations: Lapin Kansa (a newspaper company in northern Finland), Ranua Zoo (a wildlife park in northern Finland), KLKopio (a digital printing company), and LAPPSET Group (a Finnish global playground equipment manufacturer). The service development cases were conducted between 2009 and 2011. The data were collected from multiple sources (video documentations of simulation work in the SINCO laboratory, fieldwork diary notes of participatory observations, self-documented materials of the research participants) and analyzed through descriptive content analysis [34].

In this paper the foundation for the conceptual framework for service design is based on the current debates in the field. Identification of the conceptual framework is based 


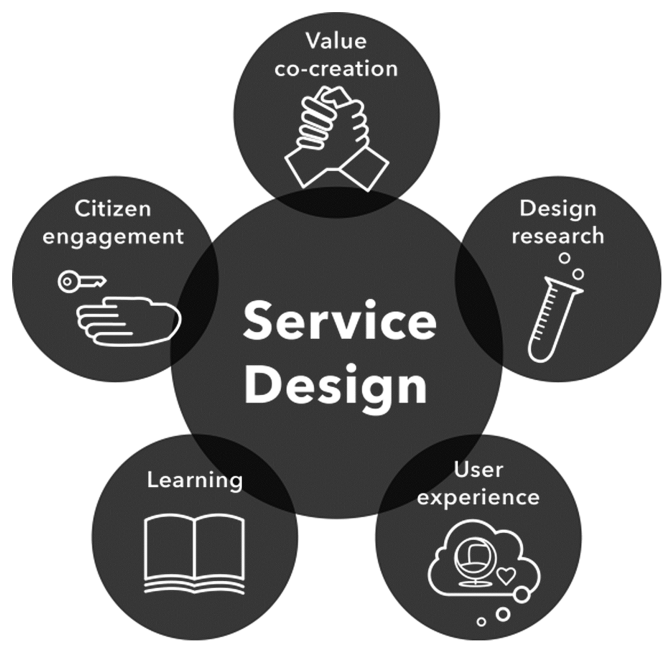

Fig. 1. The theoretical landscape of service design

on an analysis of the case studies presented in research articles. The conceptual framework presents five themes that are closely connected with service design: (1) design research, (2) value co-creation (3) user experience, (4) learning, and (5) citizen engagement (Fig. 1).

Recent research refers to service design as a catalyst for societal change. However, the ways in which service design has developed as a successful research program from the value co-creation point of view has not been fully examined in the literature.

Case study and action research approaches are widely used in the field of design research. In this research, the four company cases serve as iterations in the action research approach. Our research process followed the typical cyclical action research process: identifying the problem, gathering data, designing, performing the actions, analyzing the results, capturing the knowledge, and planning the next steps [9].

As a theoretical concept, constructive design research has strong connotations that are attached to design practice. The aim of constructive design research defies the classical scientific comprehension of the research that is yielding new knowledge. Rather it seeks to concretize the new knowledge into a form, model, or construction that can be put to use [24]. This research introduces some insights for a theoretical framework connected with the service design debate. These impacts or the new general features that are perceived are then set as a hypothesis in forthcoming research where the aim is to concretize service design value in the visualization of even more complex systems, such as systems of digital and software intensive technologies, and the public sector.

Service design addresses services from the perspective of clients. It aims to ensure that service interfaces are useful, usable and desirable from the client's point of view and effective, efficient and distinctive from the supplier's point of view. In service design solutions to problems that do not necessarily exist today are visualized and formulated into possible future services. [27] This process applies explorative, generative, and evaluative design approaches [10]. 


\section{Design Research}

Hanington [13] presented a nomenclature of research methods for human-centered design in which he introduced innovative methods used by designers where user information is collected by creative means. Sanders [42] proposed a landscape of humancentered design research where one can distinguish design-led research. Furthermore, Sanders and Stappers [43] defined co-creation as a form of creativity that is shared by two or more people. They define co-design as a specific incident of co-creation where designers and people not trained in design collaborate creatively in the design development process. Co-design work is carried out on a regular basis, and new innovative methods are developed to allow inclusion, creativity, and engagement.

Koskinen, Zimmerman, Binder, Redström and Wensveen [24] have found a constructive design research paradigm that has taken a foothold in the modern age, where design is in its third generation. They highlight the need to revisit the notion of the research programs that are in dialog with society. Raising a debate on economic competitiveness and value creation in the era of major social changes, urbanization, ageing generations, not to mention climate change are to be dealt with a concrete solution exceeding the aims of the modern era of knowledge transfer. Thus, from the commercial product development and global business point of view, the design researchers now face "wicked" problems that can hardly be solved. From the management point of view in the field of constructive design research, there are solutions of value and value propositions that are not found in rational problem-solving methods but rather by way of the methodical work of imagination and design thinking [24].

Yet, the history of service design is brief, originating within interaction design and cognitive psychology. The connection with the interaction design discipline was left in the background when programmatic research on empathic design, co-design, and action research in Scandinavia; service design and design for sustainability in Milan; and research on user experience at Carnegie Mellon began to catch the attention of design researchers. Recently, the original connection with the design "interaction" has strengthened, extending beyond cognitive psychology and toward wider areas of interest, such as identity, emotion, and embodiment. Constructive design research also has its roots in interaction and industrial design. [24]

In business and among actual companies working within the SINCO laboratory environment, the questions related directly to the management and managerial development of small and medium-sized companies have grown into the core of service design expertise. In the collaboration with the Faculty of Art and Design, service design knowledge is desired by the small and medium enterprises (SMEs) in addition to the more traditional industrial and graphic design case studies.

\section{Value Co-creation}

Service design relates to many theoretical frameworks, such as the debate on value cocreation [12, 48-50]. It is clear that service design plays a strategic role in the co-creation of value. This is realized by applying a wider approach that integrates service thinking 
and understands the user in connection with service rationales as well as the user's relationship with and construction of service propositions.

Sangiorgi [44] proposed that design researchers can work at two parallel levels. At one level, they introduce Design for Services methods with a focus on improving service experiences and offerings that are designed around customer needs. On another level, they introduce a new way of thinking about value co-creation and innovation (Service Thinking) that could transform the way organizations perceive their role, offerings, and innovation processes. Wetter-Edman [52] discussed the service design discourse in which the relationships among users, designers, and design objects are important per se. In service management, however, underlying rationales are present. There is an increasing interest in the methods and tools that are needed in order to understand the users within their context and in how to transfer that understanding into successful service propositions and profit. There is a need to see and understand the rationales as well as the relationships.

Value co-creation is understood in the context of human action. The context ties down values. The aim of the service design process is to concretize these context-laden values. From the human-centered point of view, values are bound in multiple systems of meanings that are constructed by the groups, communities, and other forms of human assemblies acting in their living contexts. These meanings can be interpreted and researched theoretically in ethnography, but from the service design and "design ethnography" perspectives, the first-hand experience of context is important in building rapid and concrete prototypes during fieldwork and to start a progressive dialog with the people engaged in the co-creation process [24].

The service design process follows much of the end-user oriented design process formula, where the first phase focuses on end-user understanding (i.e., usability and user experience), the second stage focuses on the concept creation based on user understanding, and third stage focuses on the concretization of the implemented ideas. This is how design processes are seen to move ahead.

In addition, value co-creation is bound within the context of human action, which ties down values. The aim of the service design process is to concretize these contextladen values. From the human-centered point of view, values are bound in multiple systems of meanings that are constructed by the groups, communities, and other forms of human assemblies acting within their living contexts. These meanings can be theoretically interpreted and researched in ethnography; however, from the service design and "design ethnography" perspectives, the first hands-on experiences of contexts are important in building rapid and concrete prototypes during fieldwork and to start a progressive dialog with the people in the co-creation process [24].

In the business cases run at the SINCO prototyping laboratory, the value co-creation is attached to the core of the business of the enterprise in question. Service prototyping, for one, is the core area of the SINCO activities, including prototyping of the service concepts and the customer journeys for the company involved. In addition, the companies' value co-creation process still calls for the testing and evaluation of the service design concept that is constructed. From the (positivist) scientific point of view, this would be the phase of research, whether that phase is done at the beginning of the design process for the present set of service products or in a 
final stage in order to create reliability and validity for the service concept that was constructed during the service prototyping process.

In the project for the LAPPSET Group (a Finnish global playground equipment manufacturer) [41], a student group conceptualized virtual trainer content for public outdoor spaces. The aim of that project was to create a digital service concept for physical products in order to give the company a competitive advantage in the fitness equipment market. The initial design brief included generating ideas that encouraged users to exercise utilizing touchscreens connected to gym devices. The design process followed the cyclical model, repeating working phases based on continuous hands-on prototyping. Different devices and Internet resources were utilized to concretize, understand, and develop various ideas. A remote-guided training program was prototyped with a camera and a screen. The experience of prototyping helped to develop an understanding of the socio-emotional aspects that could not be tested with paper prototypes or mere roleplaying [41].

In a student project for Lapin Kansa (a newspaper company in northern Finland) [32, 41], the aim was to develop the idea of selling newspaper subscriptions as a concrete package in a grocery store. Experience prototyping with service-scape simulation was used throughout the process, including understanding the context, composing new ideas, testing the final concepts, and communicating them to the company representative. In the concept-testing sessions, the think-aloud method was used to capture the intuitive reactions, attitudes, goals, and needs of the test users. This case study concretized the meaning of empathizing with someone else's role [32,41].

In service design the phases of prototyping and evaluation are used for value proposition purposes. Concretizing value is still out of the realm of business and managerial perspectives in that sense, but it is to be part of the value of service design. Even if service design is not able to provide a commercial method for a service design system as a construction, it is able to construct a model of future visioning and for re-imagining better futures that a company, such as Alessi, has already done for decades [24].

\section{User Experience}

The service design process has characteristics from both iterative design process goals [11] and human-centered design [16]. Service design is a process that entails an iterative cycle of design, testing, measuring, and redesign. The human-centered design process model can be applied to problem framing, information gathering and interpretation, solution ideation, development, and evaluation in developing an existing service or in designing a new service solution. Human-centered design thinking captures unexpected insights and produces innovative solutions that more precisely reflect what consumers want [6].

In the old days, products were first designed for enterprises and then marketed and sold to consumers. Today, most products are still not designed and produced in the backyard of the true customer and end user. In addition, social media are changing the definitions of communities, friends, family members, and colleagues. Still, in the field of product and service development, the common practice is to rely on usability testing 
and skip the earlier co-design and development phases, such as rough prototyping based on the assumptions of the users' needs and indescribable aspirations. As a totally subjective and a psychologically researchable phenomenon, the user experience was ignored until the humanistic paradigm change in design research [7].

Jordan [19] stated at the turn of the 21st century that we are moving from one economic era into another. His main statement is that the consumer demands associated with the previous layer or economy will not disappear during the change. For example, in the case of digital services such as cloud services, this is a question of the trust and confidence in not only the digital transfer of knowledge but also in the emotionally and socially significant contents of human life.

When experience is the key element in understanding customer behaviour, it is in this paper evaluated and compared in relation to the definitions of user experience and value, user-centered design, and user interaction widely used in the disciplines of service design, design research, and human-computer interaction [1, 5, 33, 42]. There are more and more design practices where the role of the user is proactive and the role of the designers inactive. This refers to situations where users take the initiative in adjusting their environment and applying do-it-yourself design tools that are available to them. According to von Hippel [51], reflective design conversation based on interpreting user data and projecting design ideas against it is likely to happen when the most advanced users within specific practices start improving their equipment. Still, there exist challenges on the method of development of human-centred design practices: the development of interaction operations models that are able to structure, focus, and standardize collaborative procedures in a way that still accommodates the relevant aspects of design [22].

According to Sangiorgi [44], value is no longer conceived as embedded in tangible goods created on an assembly line but as value of social, cultural, or semantic use. The end users, customers, and individuals are social creatures. They do not live in a void, but neither are they steady members of certain consumer segments for the rest of their lives. Acting socially is valuable for humans, but social value captured in the design process requires knowledge of more institutionalized traditions or regulations inside various user communities. The other possibility is to concentrate on how people are committed to acting together, as groups and communities [33].

\section{Learning}

The aim of the SINCO environment is to support experiential learning. In Kolb's [23] experiential learning model, learning is seen as a set of circumferential cycles; the learning event is constantly evolving and deepening the process. This coincides with the iterative service design process through four phases: concrete experience (feeling), reflective observation (watching), abstract conceptualization (thinking), and active experimentation (doing) [23].

The service design approach can be used to redesign pedagogical and mediation processes in cooperation with researchers and participants in various settings [29]. This research gap between simulation pedagogy and service design research was recognized at the University of Lapland, and cooperation between the Faculty of Education and the 
Faculty of Art and Design started in 2012 with the MediPro project, a simulation-based pedagogy in education and services for first aid. This research project investigated technology-supported service processes and developed a pedagogical model to support teaching, studying, and learning processes and technology at the simulation-based learning environment. Service design helped in the recognition, understanding, and development of the immaterial processes and resources related to learning and producing know-how [27].

In recent decades, participatory and collaborative design approaches have gained increasing support and interest in many areas and fields. Different methods of co-development can be used to convert tacit knowledge to explicit knowledge and, in that way, they can foster creative learning [37]. The goal is to form a common space where information is shared and a new understanding of the participants is created based on their experiences and knowledge [40].

In the service design process, prototyping most clearly represents an activity stemming from industrial design. The starting point of the development of SINCO was the analogy of a product mock-up crafting and workshop culture in industrial design. Emphasis put on the aspect for students or other user of the laboratory to feel that the SINCO laboratory, with all its technological tools and equipment, was made for the use of all. As an environment, SINCO also needed to support the experiential learning of design thinking principles and service design methods through doing.

In service design, simulations are often called service prototypes. The goal of a prototype is not to complete the design but to learn about the strengths and weaknesses of the idea and to identify new directions [6]. Service designers find service prototyping central to their work because it is collaborative, makes services visible, and helps communicate the service concept suggestions [2]. Prototypes represent product and technological and social interactions [25]. Service design methods also allow designers and users to enact or perform service experiences before they have been established in an organization [14]. According to Coughlan, Fulton and Canales [8], prototyping is a powerful means to facilitate organizational development and change.

Prototyping enables collaborative work with stakeholders when designing product service systems and multi-channel services. Already at the concept design phase, stakeholders' participation helps facilitate realization of the ideas. The service design process is constructed in a way that the values of the experimental, and in some cases "funny," learning experiences are turned into concretized features of managerial value-in short, how company representatives see some service design constructions used in their everyday practices [21].

\section{Citizen Engagement}

Service design provides tools for user engagement in public services [38]. User-led design, engagement of users, and co-design are emphasized when designing for new social innovation [36]. As Murray, Caulier-Grice, and Mulgan [36] noted in their study, "Open Book for Social Innovation", designers and design agencies like John Thackara, whose Doors of Perception network tries to cross-pollinate ideas, share 
emerging practices to stimulate creativity and, thus, create new innovation just in the area of design but also in other fields, casting a wider net. The book also mentions IDEO, Thinkpublic, and Participle and LivelWork that re-design services with users and producers. The innovative design methods used in service design enable user participation in service development [46]. This is one of the reasons why service design increasingly plays a larger role in the public sector.

Policies and reports recognize the role of design and design research methods when designing user-driven public services [35] and when furthering the role of service design in public service development [45]. The co-production of services [4, 15], where users participate in service production, is an increasingly important subject. Service design provides tools for citizen engagement and new radical service innovations. Jäppinen [17] presented service design as a means to include citizens in service development. Blyth and Kimbell [3] tied together design thinking and big society, proposing that a designer's methods can influence the resolution of social problems and can have an effect on policymaking.

Pestoff [39] recognized both economic and political reasons for European governments to include citizens in governance and the development of public services. Aging populations, growing democracy at regional, national, and European levels, and the recent global economic crisis have all affected public finances. The response to these phenomena has resulted in some general trends: the promotion of greater volunteering, the growth of new and different ways to involve users of social services as co-producers of their own and others' services, and the spread of new techniques for the co-management and co-governance of social services. In the last instance, the third sector plays a more prominent role in the development of user councils or other forms of functional representation at the local level to engage users in a dialogue about public services. These actions represent a major social innovation in the provision of public services.

The themes that are closely connected with service design, such as design research, value co-creation, user experience, learning, and citizen engagement, open up novel possibilities and challenges. The fifth theme of citizen engagement especially inspires service designers in the public sector to co-innovate with users. They help to develop novel and fresh service design tools that systematically contribute to discovery phases $[26,28]$.

However, in the public sector, there are open questions as to who is responsible for implementing the ideation and how it may be done: how does one accomplish coproduction? [18] According to Juninger [20], there are also unsolved questions related to social issues, such as questions concerning social inclusion in public management. In the public sector, "services remain first and foremost instruments for policy-implementation", claims Juninger [20].

In conclusion, based on our case study, we propose a contextual framework for service design that might also be applied as a practical tool in social engagement: a compound of human-centered design and its research, value-co-creation, user experience, learning, and citizen engagement. In response to Juniger's concern, overcoming the distrust of social inclusion and social justice in the public sector is possible. In the fields of public service and digital business, there are similarities in their large-scale 
focus and dispersed stakeholder networks, not to mention problems in identifying services' end-users. The practical and constructive research conducted in design research, value co-creation, user experience, and learning allows them to confidently enter the field of citizen engagement.

\section{Conclusion}

The theoretical landscape of service design is multi-level and multidisciplinary. According to constructive design research and service design thinking, it is also programmatic. In today's turbulent society, one essential role of service design is to bridge the gap between societal change and business. In service design, the fundamental question is how the scalability of service design tools fit, on a conceptual and theoretical level, with service design thinking in 'minor' constructions, such as SMEs' development in Finland, and major global constructions, such as population aging.

The earlier research conducted on design, co-creation, user experience, and learning now bears witness to a joint service design core that is human-centered and has a social scope of objects in service design. Whether the objects of design are focused toward public safety or digital services, the social nature of human activity remains of central importance [1, 30, 47]. However, thinking about our global society or the omnipresent digital world does not mean that social systems can ever be totally global. Distinct historical and cultural backgrounds are evidence of the diversity of social and systems that have been present throughout history. This diversity is not going to disappear, even in the digital age. On the contrary, service design has the potential to engage its attention toward human-centered perspectives in all the fields that it enters.

This research paper provides some insight into the theoretical frameworks that are connected to service design debates. This is a meta-level model of how service design is situated in design research discourses. It also outlines the theoretical background for this multidisciplinary approach from a constructive and generative research point of view. In forthcoming research, the aim will be to concretize the service design value and proceed with a visualization of more complex systems like digital and information technologies. The focus will be on building innovative programs that boost service design thinking within public organizations and business corporations.

\section{References}

1. Battarbee, K.: Co-experience: understanding user experiences in social interaction. Ph.D., University of Art and Design, Helsinki (2004)

2. Blomkvist, J.: Conceptualising prototypes in service design. Ph.D. Linköpings Universitet (2011)

3. Blyth, S., Kimbell, L.: Design Thinking and the Big Society: from Solving Personal Troubles to Designing Social Problems. Actant and Taylor Haig, London (2011). http://www. taylorhaig.co.uk/assets/taylorhaig_designthinkingandthebigsociety.pdf. Accessed 3 Mar 2015

4. Boyle, D., Harris, M.: The challenge of co-production. NESTA, UK (2009). http:// www.nesta.org.uk/publications/challenge-co-production. Accessed 3 Mar 2015 
5. Boztepe, S.: Competing theories and models. Int. J. Des. 1(2), 57-65 (2007)

6. Brown, T.: Design thinking. Harward Bus. Rev. 86(6), 84-92 (2008)

7. Bürdek, B.E.: Design: History. Theory and Practice of Product Design. Birkhäuser, Basel (2005)

8. Coughlan, P., Fulton, S.J., Canales, K.: Prototypes as (design) tools for behavioral and organizational change: a design-based approach to help organizations change work behaviors. J. Appl. Behav. Sci. 43(1), 1-13 (2007)

9. Ferrance, E.: Themes in Education: Action Research. Brown University, US (2000). http:// www.alliance.brown.edu/pubs/themes_ed/act_research.pdf. Accessed 3 Mar 2015

10. Fulton, S.: Informing our intuition: design research for radical innovation. Rotman Magazine, (Winter), 53-55 (2008)

11. Gould, J.D., Lewis, C.: Designing for usability: key principles and what designers think. Commun. ACM 28(3), 300-311 (1985)

12. Grönroos, C.: Service logic revisited: Who creates value? And who co-creates? Eur. Bus. Rev. 20(4), 298-314 (2008)

13. Hanington, B.: Methods in the making: a perspective on the state of human research in design. Des. Issues 19, 9-18 (2003). (4, Autumn 2003)

14. Holmlid, S., Evenson, S.: Bringing service design to service sciences, management and engineering. In: Hefley, B., Murphy, W. (eds.) Service Sciences, Management and Engineering: Education for the 21st Century, pp. 341-345. Springer Science + Business Media, LLC, New York (2008)

15. Horne, M., Shirley, T.: Coproduction in Public Services: A New Partnership with Citizens. Cabinet Office, Strategy Unit, UK (2009)

16. International Standards Office (ISO9241-210) International Standard: Ergonomics of humansystem Interaction - Part 210: Human-centred design for interactive systems. First Version 2010-03-15. ISO 9241-210:2010 (E). ISO, Geneva (2010)

17. Jäppinen, T.: Kunta ja käyttäjälähtöinen innovaatiotoiminta. Kunnan ja kuntalaisen vuorovaikutus palveluja koskevassa päätöksenteossa ja niiden uudistamisessa. Helsinki: Suomen Kuntaliitto (2011)

18. Jäppinen, T., Miettinen, S.: Service designing Finland - From policy to action. Touchpoint 7(1), (Forthcoming, 2015)

19. Jordan, P.W.: Designing Pleasurable Products. An Introduction to the New Human Factors. Taylor \& Francis, London (2000)

20. Juninger, S.: Public foundations of service design. In: Miettinen, S., Valtonen, A. (eds.) 2012 Service Design with Theory. Discussions on Change, Value and Methods, pp. 18-24. Lapland University Press (LUC), Rovaniemi (2012)

21. Kasanen, E., Lukka, K., Siitonen, A.: Konstruktiivinen tutkimusote: luonne, prosessi ja arviointi. In: Rolin, K., Kakkuri-Knuuttila, M., Henttonen, E. (eds.) Soveltava yhteiskuntatiede ja filosofia, pp. 111-133. Gaudeamus, Helsinki (1993)

22. Keinonen, T.: Design contribution square. Adv. Eng. Inform. 23, 142-148 (2009)

23. Kolb, D.A.: Experiential Larning: Experience as the Source of Learning and Development. Prentice Hall with Englewood Cliffs, New Jersey (1984)

24. Koskinen, I., Zimmerman, J., Binder, T., Redström, J., Wensveen, S.: Design Research Through Practice. From the Lab Field and Showroom. Morgan Kaufmann, Amsterdam (2011)

25. Kurvinen, E.: Prototyping Social Action. PdD. University of Art and Design, Helsinki (2007)

26. Kuure, E., Miettinen, S.: Considerations of common good in the co-design with publics workshops as a tool for individual empowerment. In: Nordes 2015, Design Ecologies, vol. 6 (Forthcoming, 2015) 
27. Kuure, E., Miettinen, S.: Learning through action: introducing the innovative simulation and learning environment Service Innovation Corner (SINCO). In: E-Learn (World Conference on E-Learning 2013), 21-24 October, Las Vegas, Nevada, USA (2013)

28. Kuure, E., Lindström, A.: The voices of the users - How technology can help in co-innovation. In: Farias, L.P., Calvera, A., da Costa, B.M., Schincariol, Z. (eds.) Design Frontiers: Territories, Concepts and Technologies, Proceedings of the ICDHS 2012, 3-6 September, Sao Paulo, Brazil, pp. 391-395. Edgard Blücher Ltda (2012)

29. Kuzmina, K., Bhamra, T., Triminghan, R.: Service design and its role in changing education. In: Miettinen, S., Valtonen, A. (eds.) 2012, Service Design with Theory. Discussions on Change, Value and Methods, pp. 27-36. Lapland University Press, Rovaniemi (2012)

30. Mead, G.H.: Essays in Social Psychology. Transaction Publishers, New Brunswick (2001)

31. Miettinen, S., Kuure, E.: Designing a multi-channel service experience. Design Management Review. The Changing Nature of Service \& Experience Design 24(3), 30-37 (2013)

32. Miettinen, S., Rontti, S., Kuure, E., Lindström, A.: Realizing design thinking through a service design process and an innovative prototyping laboratory - Introducing Service Innovation Corner (SINCO). In: Israsena, P., Tangsantikul, J., Durling, D. (eds.) 2012. Design Research Society 2012, Conference Proceedings, Bangkok, vol.3, pp. 1202-1214 (2012)

33. Miettinen, S., Rytilahti, P., Vuontisjärvi, H., Kuure, E., Rontti, S.: Experience design in digital services. REBCE (Research in Economics and Business: Central and Eastern Europe) 6(1), 29-50 (2014)

34. Miles, M.B., Huberman, M.: Qualitative Data Analysis: An Expanded Sourcebook. SAGE, Thousand Oaks (1994)

35. Ministry of Employment and the Economy, Finland.: Demand and user-driven innovation policy Helsinki, Finland. [e-report] Publications of the MEE: Innovation 48/2010 (2010). https://www.tem.fi/files/27547/Framework_and_Action_Plan.pdf. Accessed 3 Mar 2015

36. Murray, R., Caulier-Grice, J., Mulgan, G.: The open book of social innovation [e-book] NESTA with The Young Foundation (2010). http://www.nesta.org.uk/sites/default/files/ the_open_book_of_social_innovation.pdf. Accessed 3 Mar 2015

37. Nonaka, I., Takeuchi, H.: The Knowledge-creating company: How Japanese companies create the dynamics of innovation. Oxford University Press, New York (1995)

38. Parker, S., Heapy, J.: The journey to the interface: How public service design can connect users to reform. [e-book] Demos, London (2006). http://www.demos.co.uk/files/ journeytotheinterface.pdf?1240939425. Accessed 3 Mar 2015

39. Pestoff, V.: Innovations in public services: co-production and new public governance in europe. In: Botero, A., Paterson, A.G., Saad-Sulonen, J. (eds.) 2012. Towards Peer Production in Public Services: Cases From Finland, pp. 13-33. Aalto University School of Arts, Design and Architecture. Department of Media, Helsinki (2012)

40. Pöyry-Lassila, P., Teräväinen, H.: Yhteiskehittämisen yleisiä ja yhteisiä periaatteita. In: Smeds, R., Krokfors, L., Ruokamo, H., Staffans, A. (eds.) InnoSchool - Välittävä koulu. Oppimisen verkostot, ympäristöt ja pedagogiikka. SimLab Report Series 31, pp. 17-21. The Aalto University School of Science and Technology, Helsinki (2010)

41. Rontti, S., Miettinen, S., Kuure, E., Lindström, A.: A laboratory concept for service prototyping - service Innovation Corner (SINCO). In: ServDes2012 (Service Design and Innovation Conference), 8-10 February, Helsinki, Finland (2012)

42. Sanders, E.B.: Design research in 2006. Des. Res. Q. 1(1), 1-8 (2006)

43. Sanders, E.B., Stappers, P.J.: Co-creation and new landscapes of design. CoDesign 4(1), 5$18(2008)$ 
44. Sangiorgi, D.: Value co-creation in design for services. In: Miettinen, S., Valtonen, A. (eds.) Service Design with Theory. Discussions on Change, Value and Methods, pp. 95-104. Lapland University Press (LUC), Rovaniemi (2012)

45. The House of Commons, UK.: User involvement in public services. UK. [e-report] The House of Commons: Public Administration Select Committee (2008). http://www.parliament.uk/ pasc. Accessed 3 July 2012

46. Thomas, E.: Innovation by Design in the Public Services. Solace Foundation, London (2008)

47. Tuomela, R.: The Philosophy of Social Practices: A Collective Acceptance View. Cambridge University Press, Cambridge (2002)

48. Vargo, S.L., Lusch, R.F.: Why "service"? J. Acad. Mark. Sci. 36, 25-38 (2007)

49. Vargo, S.L., Lusch, R.F.: Service-dominant logic: what it is, what it is not, what it might be. In: Vargo, S.L., Lusch, R.F. (eds.) The Service-Dominant Logic of Marketing: Dialog, Debate and Directions, pp. 43-56. Routledge, New York (2006). First published by M.E. Sharpe Inc.

50. Vargo, S.L., Lusch, R.F.: The four services marketing myths: Remnants from a manufacturing model. J. Serv. Res. 6, 324-335 (2004)

51. von Hippel, E.: Democratizing innovation. MIT Press, Cambridge (2005)

52. Wetter-Edman, K.: Relations and rationales of user's involvement in service design and service management. In: Miettinen, S., Valtonen, A. (eds.) Service Design with Theory. Discussions on Change, Value and Methods, pp. 105-114. Lapland University Press (LUC), Rovaniemi (2012) 